\title{
THE LOWER BODY: YIN LICHUAN AND SHEN HAOBO
}

At the start of the twenty-first century, the most talked-about thing in avant-garde poetry in China was a controversial group of authors called the Lower Body (下半身). Section 1 of this chapter is a critical introduction to their poetry, poetics and poethood, with special attention to the work of Yin Lichuan and Shen Haobo. We focus on the years 2000-2002, when two book-like issues of the unofficial journal named after the group appeared and its members made their way into a wide range of other publications. The Lower Body has since ceased to be active as a group but secured a place in literary history, even if this is fiercely contested. In addition, its legacy lives on through the individual literary careers of some of its one-time members, including Yin, Shen and Duoyu. Section 2 sketches the Lower Body's lineage within the avant-garde, from three angles summarized as demystification, bad behavior and social concern. As regards the third, although the Lower Body is an extreme manifestation of the Earthly aesthetic, a feature it shares with texts across the full spectrum from Elevated to Earthly is that it regularly positions literature as a medium for the expression of such concern. This confirms that while the Elevated and the Earthly provide useful points of reference for discussing the avantgarde, they are not pigeonholes and they do not constitute a binary opposition.

The Lower Body's reception in literary circles is sharply divided. If some critics dismiss it out of hand as immoral, this is evidence of a mismatch of critical expectations and actual poetic production more than anything else, as in the crisis discourse identified in chapter One. As this chapter hopes to show, shock value doesn't suffice to explain the publicity generated by the Lower Body. Nor does the fact that Lower Body poetry is grounded in the social realities of contemporary China make awareness of these realities indispensable for enjoying this poetry as art.

(C) MAGHIEL VAN CREVEL, 2008 | DOI 10.1163/9789047442738_010

This is an open access chapter distributed under the terms of the Creative Commons AttributionNoncommercial 3.0 Unported (CC-BY-NC 3.0) License. 


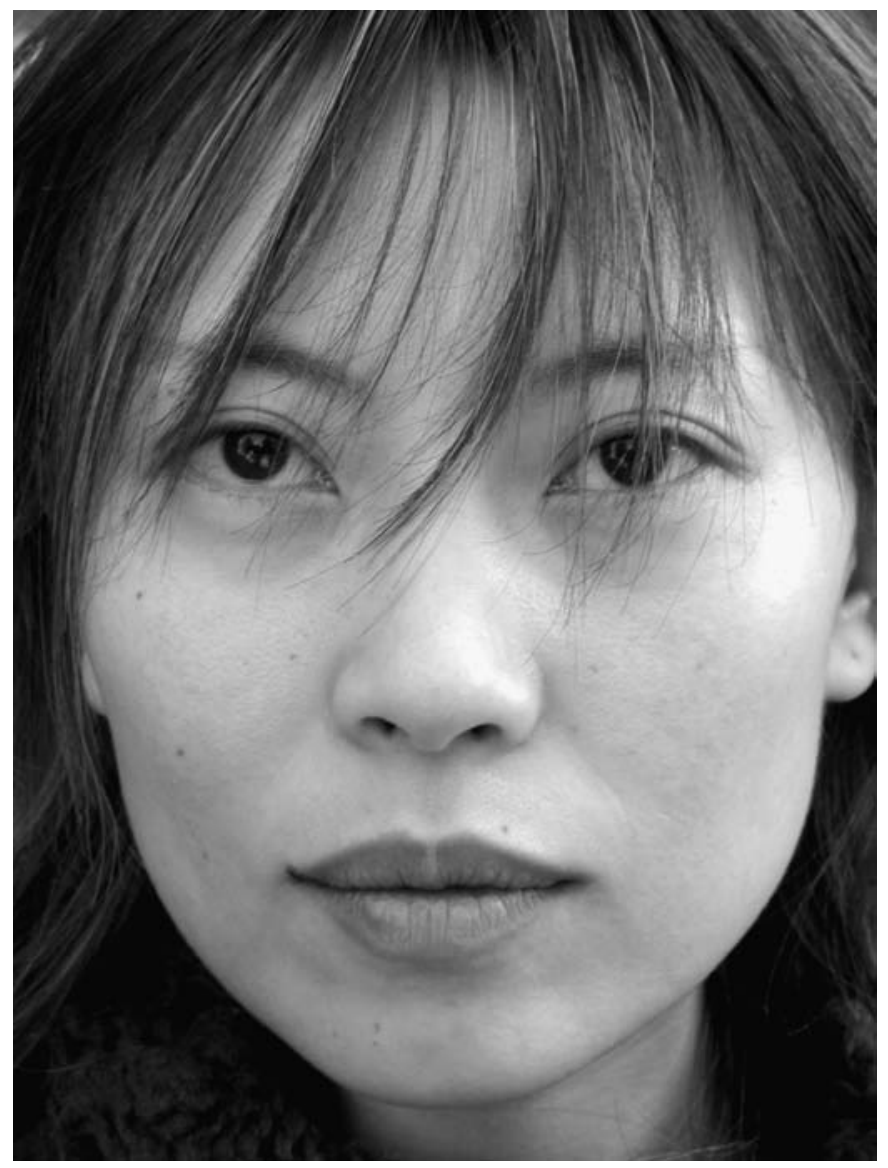

Figure 9.1. Yin Lichuan, 2004 (photograph by Martin de Haan) 


\section{Lower Body Poetry}

Here's a Chinese poem from the year 2000, Yin Lichuan's «Why Not Make It Feel Even Better» (为什么不再舒服一些): ${ }^{1}$

"Why Not Make It Feel Even Better»

ah a little higher a little lower a little to the left a little to the right

this isn't making love this is hammering nails

oh a little faster a little slower a little looser a little tighter

this isn't making love this is anti-porn campaigning or tying your shoes

ooh a little more a little less a little lighter a little heavier

this isn't making love this is massage writing poetry washing your hair your feet

why not make it feel even better huh make it feel even better

a little gentler a little ruder a little more Intellectual a little more Popular

why not make it feel even better

What is this about? Sexual intercourse, sure- but how does one have sex in an intellectual or popular fashion?

«Why Not Make It Feel Even Better» appeared in the first issue of The Lower Body, in July 2000. It is dated January 2000, when the Popular-Intellectual Polemic that had raged through the Chinese poetry scene the previous two years was coming to an end. We will take a closer look at the Polemic in chapter Twelve; for now, suffice it to note the following points. Having started as an inner-circle affair that involved numerous prominent poets and critics, the Polemic soon spilled over into the general media outside the poetry scene. Older scholars and critics in particular considered this a loss of face for literature. Their indignation over what many appeared to see as contemptible behavior on the far side of an unbridgeable generation gap was fueled by the feeling that those fanning the flames were carelessly endangering hard-won literary freedoms. After all, it was not long before that ubiquitous censorship and most of all self-censorship had set strict limits for literature, and original metaphor could lead to political interference by the authorities in the form of publishing bans, general harassment, disciplinary measures and so on. A fracas within the avant-garde, which had quickly grown and diversified since the

\footnotetext{
1 The Lower Body 1: 58-59.
} 


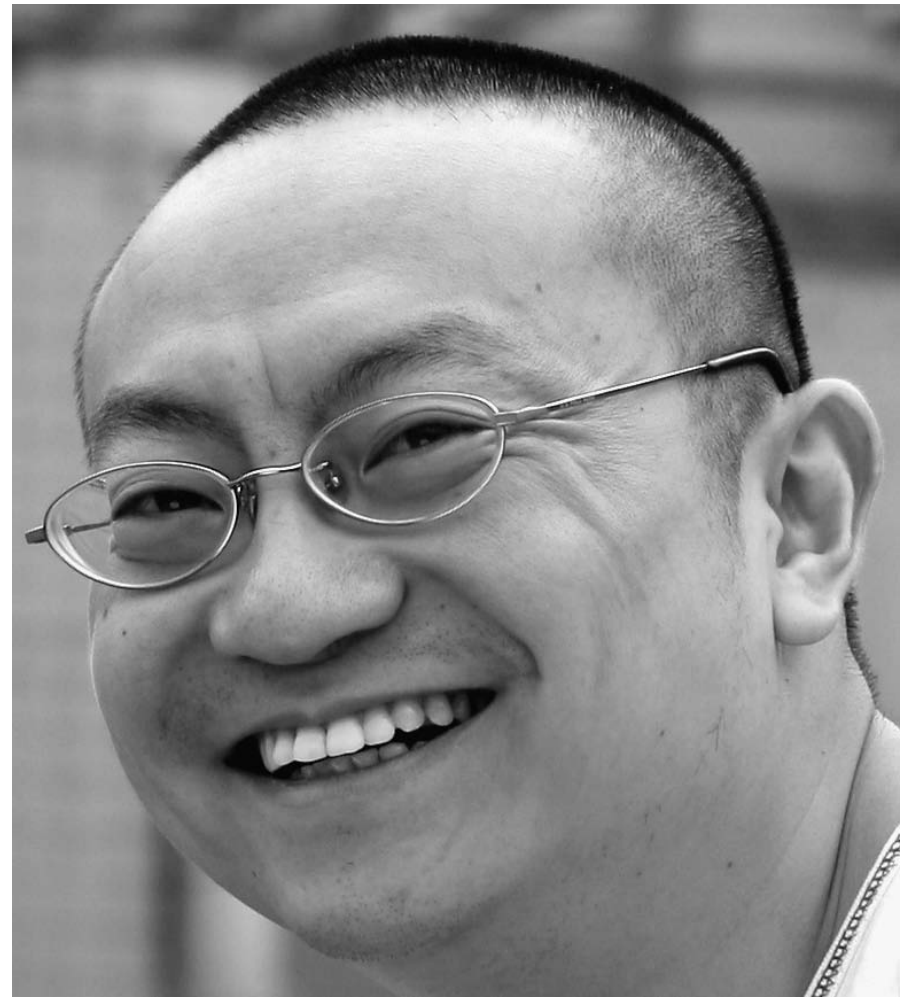

Figure 9.2. Shen Haobo, 2006 
Cultural Revolution, might just give its traditional enemy the wrong ideas. In addition, while the Polemic definitely spurred reflection on the state of the art, it also moved many to lament the damage done to poets' and critics' personal and professional relations and to the atmosphere on the scene at large, especially after the debate truly escalated during the April 1999 Panfeng Poetry Conference.

And then, early in 2000, when a sense of closure is about to descend, someone does a send-up of the whole thing. Both proud banners, carried by famous poets - such as Yu Jian, Han Dong and Yi Sha (Popular), and Wang Jiaxin, Ouyang Jianghe, Xi Chuan and Sun Wenbo (Intellectual) - appear at the end of a series of directions to get as much pleasure as possible out of sex. They do so not as the poem's focal point, but as a casual addition, almost an afterthought. This is vintage Yin Lichuan, just like the rest of the poem: derisive, tired, cynical, playful yet tough. The effect is strengthened by a dogma that holds everywhere but is particularly deep-rooted in China, certainly if one bears in mind a good two millennia of literary history: public, detailed description of sexuality is scandalous, especially if the author is a woman. ${ }^{2}$ To make matters worse, the speaker in «Why Not» is an immoral woman, whose carnal ecstasy is not the spin-off of soulmateship or love but emerges in lazy instructions to a man portrayed as a tool to satisfy female lust.

Yin Lichuan (1973) and Shen Haobo (1976) were leading members of the Lower Body group, which created a sensation from the summer of 2000 until late in 2001. Several commentators have read the metaphor of the lower body as a synonym for genitals, and equated Lower Body poetry with pornography. It is, however, too frequently ironic and insufficiently focused on sex and sexual arousal to justify this classification. There is much more to it: in its own, inimitable way, Lower Body poetry reflects "dark" sides of life in China's big cities, viewed from within the ideological vacuum surrounding urban youth who cannot find it in themselves to live conventional lives. It showcases their alternative lifestyles, which are informed by a bitter-cheerful feeling of No Future, paradoxically coupled to the sense that for the happy few in China's big cities, everything is possible. This finds expression in cynical, unconcerned individualism and hedonism, be it Punk or commercial or both. Incidentally, these are aspects of youth culture

\footnotetext{
${ }^{2}$ Idema \& Grant 2004.
} 
that are also seen in other countries, and within the mainland-Chinese socio-cultural framework their literary and artistic expression is certainly not limited to the genre of poetry.

\section{Yin Lichuan}

In Yin Lichuan's writings, then, more is to be found than the voice of an immoral woman. In the People's Republic a title like «Old Man Zhang, Retired Worker» (退休工人老张, 2000) evokes the image of a Socialist-Realist hero enjoying well-deserved retirement, or perhapsafter Colloquial poets such as Han Dong and Yu Jian - that of a quiet man from among "the common people" minding his own, daily business. But not so: ${ }^{3}$

\section{"Old Man Zhang, Retired Worken»}

when he opens his eyes, in the ceiling

there's a nail. he looks at it for ten minutes straight.

as soon as he opens his eyes, he sees this nail, in the ceiling

it's been like that for ten years straight.

so ten years ago, the nail was in the ceiling

not in his eye.

back then, as soon as he'd opened his eyes, he'd go to work - no, to the loo.

now he doesn't go to work, and he doesn't need the loo, so once he's awake

all he does is stare at the nail. the nail drops down, into his left eye.

his left eye is kaput, and can't see the nail. his right eye ain't kaput

and can't see the nail either, because the nail is now gone from the ceiling.

there's a hole in the ceiling, just like in his left eye

there's a hole. so at that hole in the ceiling

he looks with his right eye. he'll be a long time looking

before the alarm goes off, at the first glimmer of dawn

The trivial texture of everyday life - not grey hairs or other solid symbols of respectable issues in exemplary lives, but the troublesome, the hopeless, the awkward, the undignified - has been accepted subject matter in Chinese poetry since the 1980s. Yin Lichuan's power lies in her dispassionate report, in cool chatter while what happens is enough to make one cringe. Then there is her detached play with the attri-

\footnotetext{
3 The Lower Body 1: 60.
} 
butes: the nail, a left eye, a right eye, a hole in the ceiling, a hole in the left eye. The scene following the nail's descent into Old Man Zhang's eye is absurd. It revolves around the wrong eye, and asks us to believe that Zhang, nail in eye, will patiently continue to lie in bed until the alarm goes off, just as he does everyday.

Tension arises here between two types of language. One is the language of official reality as a product of socialist ideology, normally the home of people like the Old Man Zhang that appears in the poem's title. The other is the language of Yin Lichuan, who drags him away from there and into her irreverent edition of his life, in the body of the poem.

A similar stylistic twist occurs in «Man Throwing Up» (呕吐的男 人, 2000), in lines 6 and 12:4

«Man Throwing Up»

the suit is black, with filth like cream

at night a man squats in our midst and throws up

quiet and coy, everyone's most pleased.

neon dancing, women dancing

drinks dancing, music stumbling

one must be serious, thorough and fully committed.

throw up some bones

throw up some skin

throw up some fluids

throw up your last bit of vigor

and do continue. the crowd is awfully pleased.

and for the climax, pray throw in your heart and soul, my dear.

The picture is one of nightlife euphoria, intoxication and tender cruelty. An example of such tenderness, the intimacy of my dear complicates the poem's effect. This is irony, to be sure, but in Yin Lichuan's "debauched" universe - this being the sort of description typically meted out to her by detractors of the Lower Body - these words could be of the utmost sincerity.

Yin has also written sympathetically and compassionately about "unclean" characters that appeared in China's big cities late in the

\footnotetext{
4 The Lower Body 1: 63-64.
} 
twentieth century: junkies, prostitutes, petty criminals and so on. For example, in «Small-Time City Thief» (城市小偷, 2000): ${ }^{5}$

"Small-Time City Thief»»

out of a fistful of last year's snow

you squeeze a lump of black mud

empty as air. you can't find a stone to kick

and so you hold to the straight and narrow line

the streets are swept too well to offer shelter anymore

the buses are no longer crowded

you just can't get used to the girl selling shoes saying

how are you, or the shop

selling hamburgers instead of steamed rolls

fuck! all these things have changed

and no one's talking to you

big brother's gone to vietnam for big bucks

brother two's a gangleader now, brother three's been taken in

brother four was run over and killed, brother five's gone back to work the fields

and you've no place to go. in '68, you were born here

you're from the city, you've made your own life since you were small

you're no cheat no robber no rapist you're chaster than a monk

you walk past the police, careful now

but they don't even bother to look

you slow your step, people swirling

past you all the time. you set yourself down

in the city park, the fence pinching your ass

for the first time you question your beloved trade

nobody needs you now. you were born at the worng time

In addition to her ability to combine a sense of humor with credible moments of melancholy, what makes Yin one of the better Lower Body poets is her regard for poetic form, in ditty-like, playful repetition, near-rhyme and beautifully flowing rhythm. In «Wet with Paint» (油漆未干, 2001), seven consecutive lines (3-9) are syntactically and rhythmically identical, and end in the same character (度): ${ }^{6}$

\footnotetext{
5 Yin 2001: 183-184.

6 Blue 6 (2002): 112-113.
} 
"Wet with Paint»"

- dedicated to so-and-so, so-and-so and so-and-so

reach out your hands

tear off your face

measure its depth

increase its strength

rule out its filth

master its truth

shorten its length

adjust its width

reject its worth

then put it back on

(handle with care)

fix its expression

aim it at nothingness (that is, all mortal beings)

and be so kind as to stick out your tongue

to feel if your face is still there

and whether or not it is there

right where it is right then

please place your palms together

and you will certainly feel

your own devout and valiant expression

like a signboard wet with paint

on which everyone wants

to leave a pawprint

To retain the original's formal features, I have taken more translatory license than usual and rendered 湿度 'wetness' or 'dampness' as filth, 尺度 'yardstick' or 'measure' as truth and 风度 'style' or 'proud bearing' as worth.

After reach out your hands, the perfect cliché to announce a sentimental vision of love or charity, tear offyour face is of shocking brutality. The image of one's presentation to the world as a mask leads into issues of identity. Is the face-mask still there? Can one see oneself? Has the mask taken over? Can one be oneself? Just like «Man Throwing Up», «Wet with Paint» has a powerful, slightly mystifying ending. The final scene bespeaks disgust at being touched by others wanting to leave their mark, whether literal or figurative. 


\section{Manifestations and a Manifesto}

Lower Body poets without university degrees were advertised by their companions as not "polluted by knowledge." A fair number of them, however, had willingly absorbed such pollution in earlier years. Yin Lichuan studied French at Peking University, the flagship of Academe in China, and film at the École Supérieure Libre d'Etudes Cinématographiques in Paris. Four others - including Shen Haobo, the group's driving force - studied Chinese at the highly reputed Beijing Normal University. This didn't keep them from scoffing at formal education as a bastion of highbrow culture. As such, in its Earthly antiintellectualism Lower Body poetry follows on seamlessly from many Popular contributions to the Polemic. Yi Sha and Xu Jiang, two Popular polemicists who have offended just about everyone who is anyone in Chinese poetry since the early 1990s, and who are held in high esteem by the Lower Body poets, are also BNU graduates. By way of an example of the above-mentioned generation gap, the BNU connection would have contributed to Lan Dizhi's angry outburst against the Polemic at a conference entitled Chinese Literature from a Cultural Viewpoint (文化视野中的中国文学), at Tsinghua University in August 2001. It is easy to see how Lan, one-time professor of Chinese at BNU, might have felt as if he had nurtured a nest of vipers in his bosom. ${ }^{8}$

In Chinese universities, many students and professors write poetry, especially though not exclusively those in the humanities. It is not uncommon for professors or high-level administrators to encourage salon-like meetings where students "learn to write poetry." The phrase implies a different vision than that exuded by most avant-garde poetics and exhibits the continuing influence of traditional Chinese views of poetry as a skill that can be acquired rather than something requiring radical creativity and original innovation, if not deviation from the norm. Universities such as PKU and BNU produce journals and anthologies of students' poetry, recitals and awards. Such student poetry rarely rises above well-behaved, conservative burbling, in lyrical evocations of the changing of the seasons, unrequited love and weltschmerz. The original voices of the few who stand out and rise to nationwide

7 See Shen Haobo's manifesto, below.

${ }^{8}$ Cf Zhu Dake 2006: 278-279. 
fame guarantee a royal reception at their alma mater. Say, Han Dong at Shandong University, Wang Jiaxin at Wuhan University, Xi Chuan at PKU or Yu Jian at Yunnan University.

Accordingly, in December 2001, on account of the Lower Body's BNU antecedents, they met an expectant crowd of approximately four hundred at the seventh edition of the Chinese Department's Iron Lion's Cemetery Poetry Festival (铁狮子坟诗歌节); but they quickly outstayed their welcome by offending large parts of the audience. During the recital, several members of the audience walked out in protest while others voiced raucous support, until the event turned into a shouting match on the nature of poetry. A bizarre moment came when, from the high backbenches in the auditorium, a visibly enraged elderly gentleman made his way to the microphone, carrying a sword. His outfit suggested that he had come from a martial arts workout and his weaponry was for exercise rather than battle; and aside from some angry body language, his contribution was strictly verbal, amounting to a denunciation of what he saw as a disgrace to BNU and to poetry. Still, under the circumstances his sword acquired symbolic value, if only as a traditional response to the (toy) hand grenade in Diane Arbus' famous photograph of a child in New York's Central Parkwhose lower body, upside down, graces the cover of the first issue of The Lower Body. ${ }^{9}$

The journal opens with a manifesto written by Shen Haobo, entitled "For Lower Body Writing \& Against the Upper Body." The Lower Body phenomenon has been identified with these few pages to the point of eclipsing other texts, including the poetry itself. Perhaps understandably so, if only because of the manifesto's brazen style and the discrepancies between Lower Body "theory" and practice, noted by sympathizers and criticasters alike ${ }^{10}$ - even though there is no law that says an author's poetry and their explicit poetics must be consistent in order to be interesting. Here are some salient passages from the manifesto: ${ }^{11}$

\footnotetext{
${ }^{9}$ I witnessed the recital. The incident was reported in several places, e.g. Shen Haobo 2002: 101.

${ }^{10}$ E.g. Yi 2001a: 125-126 and Xi Yunshu 2001: 57-58.

11 The Lower Body 1: 3-5.
} 


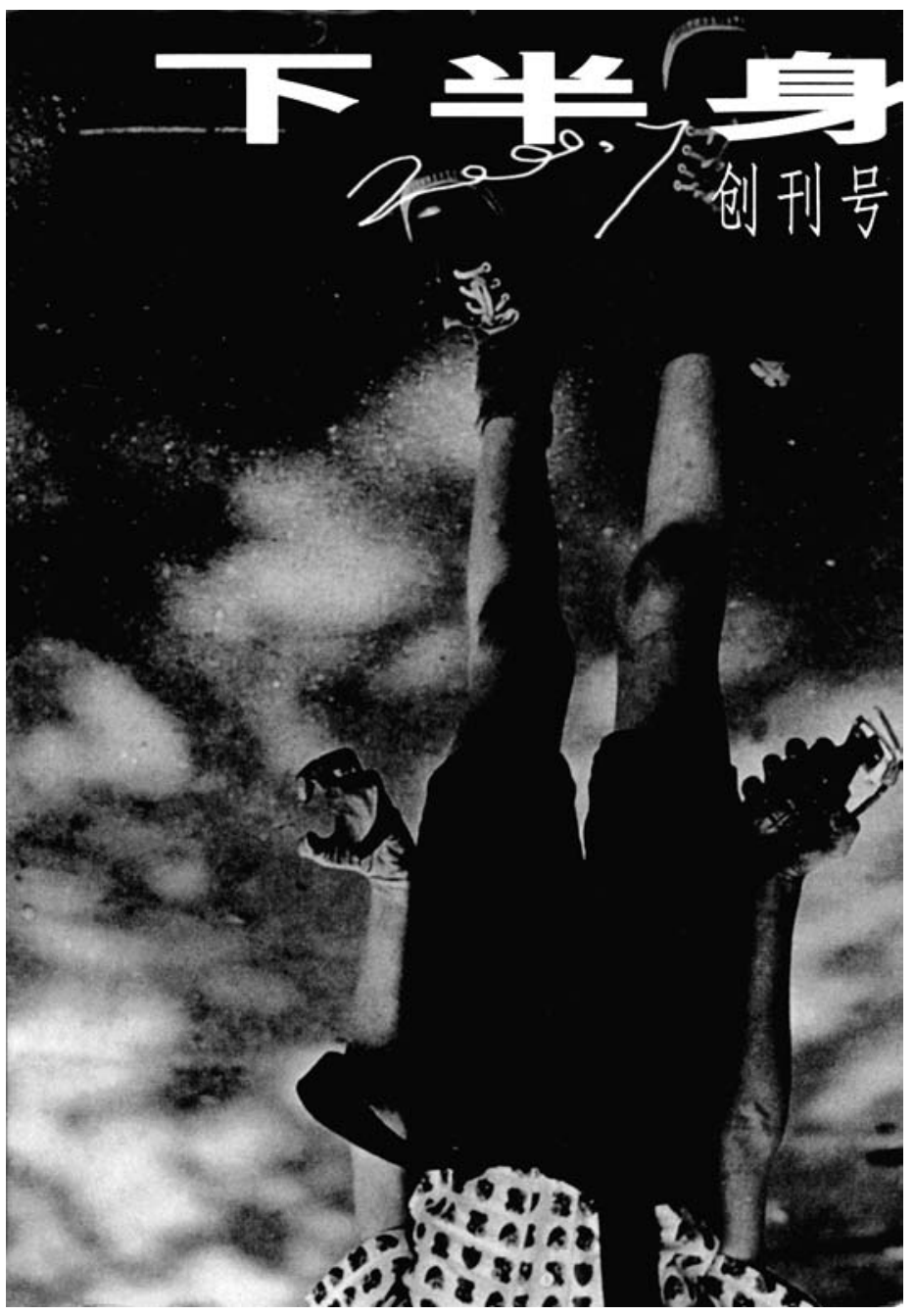

Figure 9.3. The Lower Body 1, front cover 
Emphasis on Lower Body writing means first of all the eradication of the upper body factor in poetry writing.

Knowledge, culture, tradition, poetic sentiment, lyricism, philosophy, contemplation, commitment, calling, mastership, canon ... All these words belong to the upper body and have nothing to do with art. They are entries in a humanist dictionary and have nothing to do with avantgarde poetry of the here and now.

And what is so great about the tradition of Western modern art? Nothing really. We have seen with our own eyes how an entire generation of Chinese poets have crawled before it and never stood up straight since.

As regards poetic sentiment from the Tang and Song dynasties, we are simply not satisfied with any poetic sentiment whatsoever. We are going to make poetic sentiment die a very ugly death.

Only those who can't find joy go looking for thought. Look for thought in poetry? Are you sick or something? Don't tell us you didn't know that abstruse poets are frauds. It's all the same thing: only those who can't find the body go looking for lyricism, for the sobs of a weakling. Disgusting.

Let all that upper body business go to the devil . . . We want only the lower body. That is real, concrete, tangible, exciting, wild, sexy, unimpeded.

So-called Lower Body writing means a firm worldly stand. ${ }^{12}$

So-called Lower Body writing pursues a palpable presence of the flesh. That is: of the flesh [肉体] not the body [身体] . . . For externalia such as tradition, culture and knowledge have deeply alienated, polluted and defiled our bodies. Too many people have nothing like the flesh, only a weak cultural soma, no lower body like that of animal existence, only the upper body of a pitiful thing called "human being." But to return to the flesh and to pursue a palpable presence of the flesh means to let our experience go back to that of the essential, original animal flesh. We are each of us ourselves the flesh. As the flesh happens, so poetry happens, and as the flesh makes its presence felt, so poetry makes its presence felt. That's all.

12 The word rendered as worldly is 形而下, literally 'below the form(ed), ' an antonym of 形而上 'metaphysical,' literally 'above the form(ed).' 形而下 has been used for years in social-science discourse and elsewhere, but not attained the status of a regular dictionary entry. 形而上 as the received translation of metaphysical further complicates the matter. According to the English term's Greek etymology, the antonym to metaphysical would have to be physical, if anything - metaphysical being defined in contradistinction to physical to begin with - and not involve value-laden concepts such as above and below. 
Does poetry really go no farther than language? Wrong, the time of language has come to an end, and the time of the awakened body has begun.

We lay our lower body bare, the men their hilts and the women their holes. This is how bad it is, so what have we to be scared of?

The manifesto is typical of Shen Haobo's style as a literary activist. Its recalcitrance, aggression and anti-intellectualism and the phrase $a$ palpable presence of the flesh lead to association with the atmosphere surrounding the Popular-Intellectual Polemic, as well as with Yi Sha's and Yu Jian's style in their capacity as commentators rather than poets. ${ }^{13}$ Making poetic sentiment die an ugly death is the sort of thing many self-styled innovators of artistic traditions the world over have set out to do in the age of modernity.

Even if literary manifestoes are exempt from academic assessment, Shen's argument is conspicuously flawed. Announcing that as the flesh happens, so poetry happens, he leaves one without a clue as to how this is supposed to work, a question which gains in significance if the time of language has really come to an end. The latter statement is an attack on a renowned Earthly predecessor, delivered as an aside: as noted in chapter Two, the claim that "poetry goes no farther than language" is the best-known summary of Han Dong's poetics. If one takes Shen's animal dreams seriously, problems arise as soon as he avails himself of that accursed language, especially for writing more or less expository text. Animals have no language in the human, let alone the literary sense. If human expression is figuratively animal-like, this would have to be in other art forms than literature: say, in music. The image of original animal flesh also sits uneasily with the urban-decadent style of the Lower Body group, in both life and work. In a more domesticated piece for Poetry Exploration Shen follows kindred souls such as Yi Sha, $\mathrm{Xu}$ Jiang and Hou Ma when he calls his preferred poetic usage Post-

\footnotetext{
13 See Zhongdao 1998, a partial but rich and informative collection of Yi Sha's poetry and related matter (interviews and so on), and numerous comments on his work by others; and Yu Jian 2001b, following the corporeal orientation of Yu's earlier writings such as 1999b. In Yi 2001b Yi Sha's focus on the flesh becomes a caricature, perhaps because he addresses a primary audience consisting of admirers (cf Shen Haobo 1999 and 2001b, and Duoyu 2000): the editors of The Lower Body, who likely asked him for a contribution.
} 
Colloquial (后口语). Here, too, Shen's vigor leads to little more than unproven assertions, not of the original or stimulating kind. ${ }^{14}$

Shen's first individual collection of poetry, A Handful of Tit (一把好 乳, 2001), is a garish, professional-looking unofficial publication. Its material quality reflects the fact that Shen makes a living in the publishing business as one of the many book brokers operating in newly graphomanic China, to borrow Geremie Barmé's term. ${ }^{15}$ Shen's second collection, Great Evil Hidden in the Heart (心藏大恶), banned almost immediately after its (official) publication in 2004, suggests macho sexuality through the cover photograph of a man's bare abdomen rising from a pair of jeans, his crotch at the center of the picture. ${ }^{16}$ In a preface to A Handful called "My Poetry Makes Sense" (我的诗歌有道 理), Shen claims that foreign sinologists will never understand poetry like his and neither will most Chinese critics, because they only have access to learned, intellectual, formal types of language and cannot get at the nuances of the spoken word.

It is difficult to determine the limits of one's own perception, and I am aware that the native and non-native experience of any poetry is likely to differ substantially — although generalization of this issue disregards the individual reader's engagement with the literary text that is essential to its realization. At any rate, I would wager my dictionaries that foreign readers are not as powerless as Shen makes them out to be. On the contrary, Lower Body poetry is easier for foreign readers and translators than most other avant-garde texts. This is because of its one-dimensionality or, in a related image, its textual shallowness; and because of its loose composition on the levels of word, phrase and sentence, which make the translator less obliged than usual to be "faithful to the original" in the narrow sense. Both Yin Lichuan and Shen Haobo have stated that they are less concerned with translatory word-to-word meticulousness than with getting across the "meaning" or the "intention" or indeed the "gist" (意思) of their work. ${ }^{17}$ One surmises that this attitude also holds for their poetry's domestic travels, so to speak, and that critical misapprehensions of Lower Body poetry are to do with the incompatibility of the poet's and the critic's

14 Shen Haobo 1999. The invention of the term is generally ascribed to Yi Sha (e.g. Luo Zhenya 2005: 212).

15 Barmé 1999: x.

16 Shen Haobo $2001 \mathrm{a}$ and 2004.

17 Personal communication on several occasions in 2001-2003. 
respective poetics rather than anyone's insufficient command of the Chinese language, including its colloquial or post-colloquial varieties. More generally, Shen's low appraisal of Chinese and foreign critical ability - and of much avant-garde poetry to date - appears to be part of mechanisms of differentiation and dissociation from what has gone before which typically come into play when a new trend seeks to establish itself in the literary field.

Clear-cut distinctions between high and popular culture have been effectively challenged in the past several decades, and so has the automatic evaluation of high as good and popular as bad. Still, I wish to note that the aforesaid one-dimensionality and shallowness are not value judgments or euphemisms for bad poetry. Successful Lower Body texts combine a particular flow, colloquial or theatrical or both, with the effective evocation of an extra-literary, acutely relevant context. This context is an urban jungle, home to insatiable industries of consumption and entertainment, in a society witnessing the rise of money, social mobility, inequity and sex as something no longer linked to wedlock, love or procreation. These things are proportionate to the collapse of Chinese-socialist ideology and its institutions in all spheres of life: material austerity, the iron rice bowl, puritanism and so on. In Lower Body poetry the new New China is experienced through the senses of hip, free-floating youths who fail to meet society's conventional expectations but who are smart and well-connected enough to get by, with a keen eye for both misery and happiness.

\section{A Comparison with Glamlit}

The Lower Body is firmly grounded in the turbulent social realities of contemporary China outlined above. If, as part of the poetry scene, it emerged in a climate that had been generated by the Polemic, this is only one of several possible angles from which to approach these texts. Hence, before we proceed to examine Shen Haobo's poetry, a quick comparison with related developments in fiction - much better researched to date - is in order.

Following the relaxation of government cultural policy in late 1970s China, Obscure Poetry and, for fiction, Scar Literature (伤痕文学) embodied a transition from orthodox Maoist poetics to experimental 
or avant-garde types of literature. ${ }^{18}$ Both poetry and fiction have since thoroughly problematized their status as high art. Anti-intellectualism, the celebration of "hooligan" (流讯) lifestyles and the exploration of sexuality beyond current convention are manifestations of the shock value of literature that has foregrounded the city and the body as prominent themes, during the 1980s and especially since the 1990s. For fiction, scholars such as Robin Visser and Lu Jie have shown that the city is a site of both glamor and ugliness, and of the alienation and anxiety that modernity and globalization bring. ${ }^{19}$ The (sexual) body becomes extra significant in women's writing, because of age-old sexist bias coupled with traditional biographist views of literature that equate the speaker in the literary work with the historical person of the author. All this takes place against a backdrop of the sweeping commercialization of culture and the arts.

Going on from there, let's compare Lower Body poetry with fiction by the equally controversial women authors known as Glamlit Writers or Beauty Writers (美女作家), specifically Weihui's Shanghai Babe (上海宝贝, 1999) and Mian Mian's Candy (糖, 2000), with reference to research by scholars including Megan Ferry, Sabina Knight, Sandra Lyne and Kong Shuyu. ${ }^{20}$ There are similarities in that Yin Lichuan's, Shen Haobo's and Weihui's allegiance with youth culture and their anti-intellectual and "hooligan" claims are complicated by the strategic downplaying of their own formal training - Mian Mian is the only one without a degree from a prestigious university - and by the fact that their readers far exceed the scope of youth culture and include many intellectuals and few hooligans. This brings to mind the ambiguities in Hooligan or Thug Literature (流讯文学、㾂子文学) godfather Wang Shuo's relation to high culture, as noted by Wang Jing, even if it would have been unrealistic to expect a seriously hooligan readership for Wang Shuo's work to begin with. ${ }^{21}$

Neither the Lower Body nor Glamlit fiction make sexual passion a substitute for political, Maoist-revolutionary passion, an operation identified by Wendy Larson in Anchee Min's Red Azalea. ${ }^{22}$ In the work

\footnotetext{
${ }^{18}$ Yeh 2003: 525, Knight 2003a: 528-529.

19 Visser 2002, Lu 2004.

${ }^{20}$ Weihui 1999, Mian Mian 2000, Ferry 2003, Knight 2003b, Lyne 2002, Kong 2005: ch 4.

${ }^{21}$ Wang Jing 1996, chapter 7: e.g. 284.

${ }^{22}$ Larson 1999.
} 
of Yin Lichuan, Shen Haobo, Weihui and Mian Mian, politics is largely irrelevant. At the same time, their individual focus on low-life and lawless losers, decadent consumers of sex \& drugs \& rock-n-roll and other inhabitants of the new urban jungle is inseparable from social change in 1990s China. This, in its turn, has a political dimension, if only in the debunking of political ideology as one of the primary factors shaping social policy.

The emancipatory potential of sex, also discussed by Larson, is central to Ferry's and Knight's research and features in Kong's investigation into the commercialization of literature. Here, we find important differences between the Lower Body and Glamlit. At the same time as raising questions of womanhood, ethics and morality, Weihui and Mian Mian ultimately reinforce stereotypes of female sexuality, against a backdrop of the continuing repression of women. Shen Haobo's rude machismo works differently in that it can alternatively be read as a sarcastic indictment of male chauvinism. Similarly, Yin Lichuan plays with female stereotypes, in caustic and triumphant ways that enhance female literary agency and self-representation - whereas Glamlit fiction undermines these things, as Ferry shows. We find another sexuality-related contrast between Glamlit and the Lower Body in Lyne's classification of Shanghai Babe as yet another example of the long-standing, exoticizing sexualization of Asian women, catering to the demands of the (foreign) male gaze. This is not at all how female sexuality appears in Yin Lichuan's poetry. Incidentally, in contrast to Weihui's active stimulation of sex-related publicity for her work, Yin notes that there is only so much one can say about sex, remarking that the Western media hype surrounding Shanghai Babe was motivated by an interest in social issues rather than literature. ${ }^{23}$

Related to the previous points, a major difference between Lower Body poetry and Glamlit is that (international) publishing market forces are a powerful factor spurring Glamlit fiction and its graphic depictions of sexuality, and that the publishers are not just after the prestige - including, of course, notoriety - but after the money. In this respect, the situation of Lower Body poetry is captured in the observation that most of it appeared in print and online unofficial circuits, which never involve financial profit, and that all of it belongs to a literary genre that is financially unmarketable, to which we now return.

${ }^{23}$ Yin \& That's Beijing 2004. 


\section{Shen Haobo}

Shen Haobo's drive finds more felicitous expression in his poems than in his expository prose. In «Fucking Cabdriver» (他妈的出租司机, 2000), the speaker is behind the wheel of one of the seventy thousand taxis that were operating in Beijing at the turn of the century: ${ }^{24}$

\section{"Fucking Cabdriver»}

"all this fucking traffic from liulichang to majiapu on yangqiao $i$ was stuck for a full fucking hour it's fucking stop-n-start today"

“the lady i just dropped off she's got herself a fucking lover

that old girl $i$ know her she's at the fucking trade center"

"at night they're fucking everywhere see those big trucks driving so fucking fast you going somewhere stay in shijiazhuang what the fuck you in beijing for"

"now what you standing in the road for you shouldn't fucking stand anywhere this time of night why the fuck you causing trouble"

"it's really fucking fucked a shitty bridge like that nine months it ain't done yet they fucking fleecing me and you the ringroad fly-over just took six fucking months"

"see that tree with the dirty great dent a fucking toyota hit it just the other day you get sleepy you take a break right it's like he wanted to fucking die ain't it"

"but if he'd really fucking died he wouldna had to worry about the car broke the fucking axle that fella's gonna have to spend a lot of money"

"said they were gonna fix this road but nothing's happening

it's a real fucking pain now that's a job in hand eh"

"you live in fucking majiapu man you've found yourself some place

right out in the sticks how'd you fucking find it"

Taxi drivers rave and rant everywhere, in taxi driver language: politically incorrect, riddled with expletives, in monologues that are something of a natural genre in other solitary yet interactive professions too-hairdressers, shopkeepers and so on. Something very close to a Duchampian ready-made, Shen Haobo's taxi driver is no exception. Most of Shen's other poems also require little knowledge of China from the reader. His thematics include a hatred of teachers and edu-

24 Shen Haobo 2001a: 93-94. 
cation, the horrors of marriage and pedestrian middle-class existence, the new rich, emotionally indifferent sex, thugs, whores, street gang violence and so on. Shen's poems are occasionally funny and usually aggressive, and contain many colloquialisms, not idiosyncratic or experimental but delivered with considerable panache. The lines are either very short or very long; let's first consider an example of the former. «Huang Si's Ideals» (黄四的理想, 2001) makes one or two references to Chinese realities, but in such a way that a modicum of historical knowledge on the part of the reader will suffice: ${ }^{25}$

"Huang Si's Ideals»

huang si and $i$

sit on his balcony

drinking beer

playing dice

huang si is always

lucky at dice

just like he's been

lucky in business for years

he blowes into his hands

and says

if $i$ throw a six

i'll realize

my first ideal

before the year's out

buy a cadillac

and drive across the square

of heavenly peace

he blows again

and if then

$i$ throw another six

i'll also realize

my second ideal

then i'll pay a million

or two million

to book our high school teacher

that woman

25 Shen Haobo 2001a: 59-60. 
called xu chunping

the old girl

for all of two months

i'll peel off her clothes

and squeeze her

shriveled tits

while $i$ make her

tell me about

marxist-leninist thinking

One can imagine the words being uttered in stops and starts between sips of beer and throws of the dice, and this is in fact how Shen Haobo recites the poem, with end-stopped lines throughout. ${ }^{26}$ Elsewhere, Shen's and other Lower Body poets' short lines are little more than a gimmick. They are most effective when their form contributes to a content of aversion, refusal, denial and so on, whether blunt and straightforward or through irony, as in the sarcastic portrayal of idealism. One could call this type of writing rejective - again, without passing value judgment.

Shen's long-line poems are few, and generally better than his stops and starts. «And We Push» (我们拉, 2001), ${ }^{27}$ with pushing-for the Chinese 拉, literally 'pull'—denoting defecation, as in 拉屎 'take a crap,' has a recurrent chorus that both friends and foes of the Lower Body will cite to vindicate themselves. So does «All Hail the Clap» (淋病将至, 2001). Its line length is extreme even by Chinese standards and the translation below-just like Yu Jian's poetry, in smaller type and with indentation - has two more line breaks in each stanza than the original. The poem has close to a dozen sizable stanzas, maintaining a breathless speed throughout. I cite it in full so as to give the reader a sense of what one may call its aggressive size.

The bookstore in line 1 is Fangzhou (方舟书店), near Baiwanzhuang in Beijing, which sold all manner of subcultural and countercultural products in the 1990s. The rock club is the Joy Garden (开心乐园), near Wudaokou, which hosted underground rock bands until the Beijing demolition specter put an end to that, or budget problems, or both. Early in the twenty-first century this location lay in ruins, surrounded by car repair shops and illegal CD vendors. There

${ }^{26}$ Q \& A session, De Centrale (Gent, Belgium), May 2004.

27 Shen Haobo 2001a: 14-15. 
starts Shen's tirade: about money, the hunt for a green card, the tainted Tiananmen Square as a metonym for the poker face of China's autocratic rulers, faded lust, provincial officials on their junket to the sinful big city, and of course uninvolved sex: you've got yours and i've got mine just one more kiss and nothing else. The entire poem bespeaks social concern - albeit of the rough-edged kind and alternated with shameless, hard-boiled cynicism - which is visible in lines such as migrant workers on the run and that thing squatting by the road is a man not a dirty dog. The image is part of Shen's description of the gigantic construction site that Beijing has been for years, covered by deafening machines and blinding floodlights and kept running day and night by migrant workers without much in the way of labor rights. The speaker himself ends up like all the others who have no home to go to, that is: in the street and dripping with rain-yet the poem exudes undaunted resilience throughout. ${ }^{28}$

\section{«All Hail the Clap»}

and the hippest bookstore has closed

and the hippest rock club has quit

and your old man's smashed up that hard-earned bass guitar

and your childhood mates have learned to make money

and young artists have no home to go to

and they're out on the street and they're dripping with rain

drip drip drip drip drip drip drip-a-drip

dripping and dripping

now all hail the clap

and the world trade center's collapsed

and the pentagon's been bombed

and the statue of liberty's been forgotten

and the yanks look at foreigners with green eyes

and green card holders have no home to go to

and they're out on the street and they're dripping with rain

drip drip drip drip drip drip drip-a-drip

dripping and dripping

now all hail the clap

${ }^{28}$ Shen Haobo 2001a: 155-159. 
and it'll soon be national day

and then they'll cordon off the square again

and the neighborhood guards will be carrying truncheons

and they'll deal with whoever's up to no good in the parks

and migrant workers on the run have no home to go to

and they're out on the street and they're dripping with rain

drip drip drip drip drip drip drip-a-drip

dripping and dripping

now all hail the clap

and those yellowed cheekbones are sticking out more and more

and those wrinkles covered in eye-shadow are spreading

and those tight leggings make you look like a hillbilly

and the lads on the bus can't bring themselves to touch your ass

and faded women their looks swept off in a beijing dust storm have no home to go to

and they're out on the street and they're dripping with rain

drip drip drip drip drip drip drip-a-drip

dripping and dripping

now all hail the clap

and the gum in your eyes gets thicker and thicker

and you've had two abortions already

and dear min dear y a dear lan dear mali you're all so dumb

and grown men are no good have you figured it out now

and little girls one fag left in their pockets have no home to go to

and they're out on the street and they're dripping with rain

drip drip drip drip drip drip drip-a-drip

dripping and dripping

now all hail the clap

and the north wind makes the windows rattle

and birch trees shiver with cold

and old men in overcoats hunch their shoulders

and made-up mothers and aunties have nowhere to dance

and long-skirted birds that'll flaunt it at good old houhai have no home to go to

and they're out on the street and they're dripping with rain

drip drip drip drip drip drip drip-a-drip

dripping and dripping

now all hail the clap 
and at twenty you get fat

and at thirty they cut out your gall-bladder

and at forty you're out of breath after doing it once with a crumpet

and at fifty you're dead in the street

and dumb shits who squander their prime like booze have no home to go to

and they're out on the street and they're dripping with rain

drip drip drip drip drip drip drip-a-drip

dripping and dripping

now all hail the clap

and the beijing madam talks down to you

and this here ain't no backwater like your own

and one shot'll cost you three hundred no less

and if you've got dollars that's even better

and countryside deputy heads of department have no home to go to

and they're out on the street and they're dripping with rain

drip drip drip drip drip drip drip-a-drip

dripping and dripping

now all hail the clap

and he's sent his daughter to harvard

and rich daddy himself drives a big old mercedes

and from the fourth ring road you can see the fifth

and a big old au-di will take you straight to the au-lympic village

and the motherland and the people have reached an understanding

and the poor and the artists spoil the city's pretty face

and why not chase'em all into the street dripping with rain

drip drip drip drip drip drip drip-a-drip

dripping and dripping

now all hail the clap

and who says time flies when you're having fun

and who says steamed buns are good when you're hungry

and that thing squatting by the road is a man not a dirty dog

and why all the gullies below every highway

and $i$ write and $i$ write and $i$ 'm just about getting high

and a little hurt if you call me affected

and why not chase bastards like me into the street dripping with rain

drip drip drip drip drip drip drip-a-drip

dripping and dripping

now all hail the clap 
and $i$ met this woman called cao yuan we got a little tipsy

and she sang me some shaoxing opera from "the broken bridge"

and $i$ should know now what is meant by roaming eyes

and orchid fingertips scratching the night light

and you've got yours and i've got mine just one more kiss and nothing else

and $i$ slung on my bag and turned and walked downstairs

and all those me's shaved heads in threads in the night streets dripping with rain

drip drip drip drip drip drip drip-a-drip

dripping and dripping

now all hail the clap

dripping and dripping

now all hail the clap

drip drip drip drip drip drip drip-a-drip

dripping and dripping

now all hail the clap

dripping and dripping

now all hail the clap

now all hail the clap

now all hail the clap

now all hail the clap

now all hail the clap

Especially if read aloud and with the appropriate, relentless drive, such as during the BNU recital in 2001, "All Hail the Clap» is truly typical of Shen's style. It gives a memorable voice to the human experience at the root of Lower Body poetry: hopeless, yet irrepressible.

It also serves to remind us - with reference to the above discussion of one-dimensionality and textual shallowness - that many Lower Body poems are very much suited to the immediacy of recitation. As for their realization on the page, this is highly worthwhile too, even if it doesn't mobilize close-reading strategies in the reader. Lower Body poetry doesn't trigger the painstaking interpretation of syntactic ambiguity or original metaphor, or the identification of sophisticated intertextualities. This does not invalidate its artistic potential, as long as we allow it to activate the appropriate reading expectations; nor does it make the context evoked any less relevant and disturbing. On the 
contrary, the very presentation of these texts as poetry can deepen our understanding of contextual issues such as those laid out above-life in the urban jungle and so on-by offering alternative, unusual angles to complement what we learn through other media and genres. At the same time it leads to reflection on the nature of poetry and reaffirms one of the genre's fundamental features, as we shall see below.

\section{Production and Reception, Cast - But Why Poetry?}

The Lower Body is the first event in Chinese poetry that is inseparably linked with the Internet, which was the perfect medium and milieu for these texts and their authors to find their readers and develop. ${ }^{29}$ The Internet invites swift, nonchalant textual production, and for the censor it is even harder to keep up with than printed matter in the People's Republic, although visions of the web as incapacitating censorship have failed to materialize. As noted in chapter One, online varieties of the literary experience are fast gaining ground in China and may well be the default situation for the youngest generations, but there are many authors and readers for whom one measure of success for such Web Literature (网络文学) continues to be its eventual appearance in print. Accordingly, while the importance of the Internet for the emergence of the Lower Body is beyond all doubt, it has also left an impressive paper trail, including scattered translations into various languages since roughly $2003 .^{30}$

In 2002 Fu Mahuo compiled Poetry Vagabonds: Selected Web Poetry from 2001: The Avant-Garde Poetry Files (诗江湖: 2001网络诗歌年选: 先锋 诗歌档案), a multiple-author anthology whose allegiance lies with the Lower Body's literary lineage. The book is officially catalogued under this title in its Chinese Publications Library (中国版本图书馆) colophon. Much more visibly, however, the cover has Poetry Vagabonds: The Avant-Garde Poetry Files. This shorter name glosses over the web factor, reinforcing the impression that print publications have by no

${ }^{29}$ For avant-garde poetry websites, see the DACHS poetry chapter and Inwood 2008: ch 2. On Yin Lichuan as "internet poetess" and "bloggeress," see Blume 2005, Yin \& Bradbury 2005 and Hirsch 2007: ch 1.

30 Cf Inwood 2008: ch 2. On the continuing significance of publication in print, see Hockx 2004: 121 and Inwood 2008: ch 3. For English translations of Yin's and Shen's poetry, in addition to publications in The Drunken Boat 6-I/II (2006, online) and Full Tilt 1 (2006, online), see Index on Censorship 35-4 (2006). 
means lost their edge in terms of status for all authors and readers. The cover also appropriates the metaphor of the lower body for a range of authors far exceeding the group of that name in an advertising slogan that reads "the lower body of Chinese poetry." The Lower Body group itself, too, boasts a series of old-fashioned paper publications. First of all, there are the two issues of its book-like journal, from July 2000 and March 2001. In 2001 Yin Lichuan and Shen Haobo each published their first individual collection - Yin's is called Make It Feel Even Better (再舒服一些) and also contains fiction and short essays, Shen's is A Handful of Tit, mentioned earlier. The second issue of Wu Wenguang's exquisite Document (现场) series, and the sixth issue of Blue (蓝), a poetry journal put out by Chinese living in Japan, ran special features on the Lower Body in 2001 and 2002 that included poetry, biographical and bibliographical notes, interviews, verse-external explicit poetics, criticism and so on. In 2004 Shen published the abovementioned Great Evil Hidden in the Heart, which the authorities banned, retroactively classifying The Lower Body as an illegal publication in the process; and a survey collection of Yin's poetry called Cause and Effect (因果) appeared in 2006. By then, the Lower Body was no longer active as a group but Yin had become an author of considerable renown, with several readings abroad to her name. Publications featuring other Lower Body poets include anthologies such as Huang Lihai's Selected Poems by Post-70 Chinese Poets ('70后诗人诗选, 2001), Fu Mahuo's Poetry Vagabonds and many more in recent years; and unofficial journals such as Poetry Reference (诗参考), Sunflower (葵), Poetry Text, Poetry and People (诗 歌与人), Original Writing (原创性写作) and Poetry Vagabonds (诗江湖), the precursor of Fu's eponymous anthology. ${ }^{31}$

The original of the phrase poetry vagabonds is 诗江湖, literally 'poetry rivers and lakes,' 江湖 'rivers and lakes' being an age-old, somewhat sentimental term for a world of wanderers and drifters living by their wits and their prowess, on the periphery of law and order or beyond: fortune-tellers, traveling actors, prostitutes, knights and desperadoes. While the image of the poetry scene as one of vagabondage is by no means exclusively linked to the Popular-Intellectual Polemic, it has been a favorite with advocates of Earthly types of poetry ever since the first blows were exchanged. Xu Jiang, for instance, addresses the Intel-

${ }^{31}$ Fu 2002, Yin 2001, Shen Haobo 2001 a and 2004, Yin 2006, Huang Lihai 2001. 
lectuals using a rhymed saying in popular martial arts fiction (武侠小 说) style: “Go ahead, wander rivers and lakes in this life, and we'll see who's the first to fall prey to my knife!” (尔等但在江湖飘, 看谁先挨 我的刀!). . $^{32}$

As for its reception, the Lower Body was the most talked-about thing in Chinese poetry in the first few years of the twenty-first century, with recorded discourse sharply divided in its tone and overall assessment. This ranges from anonymous praise and blame on the web to long essays by well-known critics in literary and scholarly journals and books. Let's consider a few examples.

Ma Ce's "The Death of Poetry: On the Need to Guard against the 'Lower Body' Poetry Group Running Wild on a 'Crash-Hot' Road' (诗歌之死: 主要是对狂奔在 “牛 B” 路上的“下半身” 诗歌团体的 必要警惕) is a furious piece, published in Lotus (芙蓉) early in 2001. The word rendered as crash-hot is 牛B, literally 'cow's cunt,' a profane expression of enthusiasm or admiration that Ma uses sarcastically, echoing Lower Body self-advertising slogans; upper case $B$ and the character 逼 are homonyms used to circumvent the taboo on the slang expression for vagina in writing. Ma contextualizes the Lower Body within Chinese poetry and indicts it for self-indulgent tendencies and the explicit aim of creating a stir. He warns that the Lower Body's predilection for profanities is pushing poetry toward the abyss of hedonism. In line with this vision he remains unreceptive to anything about the Lower Body that might possibly be worthwhile. Writing in Poetry Exploration later that year, Xi Yunshu remarks unfavorably on web-related features of the contemporary scene, and on literary activists' lack of background knowledge behind their sloganeering. Xiang Weiguo, author of Shouts from the Margins: A Genealogy of Poets of Modern Han Poetry (边缘的呐喊: 现代性汉诗诗人谱系学, 2002) - with Han referring to the Chinese language rather than ethnicity, just like the unofficial journal mentioned in chapter One - sides with Ma Ce. Xiang also notes that the first section in Yang Ke's 1999 Yearbook of China's New Poetry (1999中国新诗年鉴) already singles out a number of poets later associated with the Lower Body group, and that as such the Lower Body is less "new" than it would like to believe itself to be. He expresses disbelief at the claim, made in the journal Poetry Vagabonds,

${ }^{32}$ Xu Jiang 1999b: 90. The original idiom runs 人在江湖漂, 谁能不挨刀! 'Wandering rivers and lakes in this life, who can avoid falling prey to the knife!' 
that the collective name they later adopted substantially changed their writing styles. ${ }^{33}$

Other critics are much more positive, continuing a trend of growing literary tolerance across the history of the avant-garde at large, as observed in chapter One. They view the Lower Body as not just a particularly irreverent offshoot of Earthly poetics and a force challenging stagnation and incrowd culture but a real contribution to literature. Yi Sha and Xu Jiang are themselves poets and representatives of the Earthly aesthetic that includes the Lower Body. If they cannot be called disinterested parties, this doesn't automatically disqualify them as commentators. Writing in the same issue of Lotus as Ma Ce, both support the Lower Body cause, while warning against the dangers of the general hullabaloo's obstruction of poetry itself (Yi Sha), and of wanting to be cool for cool's sake (Xu Jiang). Xu calls Shen Haobo a poetry freak, with regard to his astonishing activism: authorial, editorial, critical, organizational and so on. Xie Youshun, writing in Flower City, also in 2001, mobilizes an impressive amount of theory to make a case for the Lower Body. This ironically recalls the desire of the Lower Body and related trends to tear down ivory towers in literature and criticism, and confirms their allegations that professional readers tend to speak incomprehensible jargon. In itself this need not invalidate Xie's argument. He outlines a fundamental opposition of the Lower Body on the one hand and Haizi - as the epitome of a larger, "lyrical" trend - on the other. The latter's "martyrdom" and mythification, following his suicide, continue to infuriate Yi Sha and Xu Jiang as well, as we have seen in chapter Three. Xie cautions against a narrow vision of the Lower Body, meaning too much attention to genitals and sex. Writing in Poetry Exploration in 2002, Chen Zhongyi lists corporealized writing (肉身化写作) as one of four important directions in contemporary poetry. He expands this section of his survey in another positive review, published in the same year in the Lower Body special feature in Blue, with the unofficial status of this journal allowing him greater candor on Lower Body subject matter and language. Chen advocates a balance of the corporeal and the mental, of the senses and the mind; and he sees Lower Body poetry as inseparable from social change and web culture. Zhang Qinghua's preface to China's Best

${ }^{33}$ Ma 2001, Xi Yunshu 2001, Xiang 2002: 173-176, Yang Ke 2000, Shen Haobo \& Yin 2001. 
Poetry of 2001 (2001年中国最佳诗歌, 2002) is an inspirational essay that portrays the Lower Body as a sign of innovation and the core of a literary generation that had just been identified in Chinese-domestic criticism at the time: Post-70, meaning that the authors in question were born after 1970. Zhang reminds the reader that avant-garde shifts away from the Elevated and toward the Earthly, which started in the mid-1980s, have never yet managed to enter the vision of the "common" people and that all avant-garde writing remains part of elite culture.

In recent years, the Lower Body has secured a place in literary history. By way of an example, Luo Zhenya's 2005 survey history On the Avant-Garde after Obscure Poetry dedicates a full chapter to Post-70 poetry, with the Lower Body as the top-of-the-bill act (领衔) mentioned in the chapter's title. Luo presents a balanced account that recognizes the Lower Body's significance as the main representative of Post-Colloquial Writing, the other constituent of Post-70 poetry being what he calls the Academicized Writing (泛学院化写作) of authors including Hu Xudong, Jiang Hao, Jiang Tao, Wang Ai and Zhou Zan. Within the Post-70 framework, these two strands can be seen as affiliated with the Earthly and the Elevated, respectively. Luo rightly notes that one of the Lower Body's distinguishing features - and of Post-70 poetry at large - is that it has produced many "happy texts" (快乐的文本) and displays little suffering (痛苦) of the kind one may encounter in other poetry. He concludes that publicity-wise, Post-70 poetry, with the Lower Body as its trailblazer, has enough of a presence to pose a real challenge to previous literary generations such as the Third Generation and Poetry of the Nineties, but that its promise needs yet to materialize. Another instance of recognition of the Lower Body as part of contemporary culture - and, within that culture, of a lineage of bad behavior, to which we turn below-is found in Zhu Dake's The Hooligan Banquet: Contemporary China's Hooligan Narrative (流讯盛宴: 当代中国的流讯叙事, 2006). Zhu comments approvingly on Yin Lichuan's poetry. He writes of Shen Haobo's work in disparaging terms, but does note the force of Shen's literary activism. ${ }^{34}$

Of the damning reactions sampled above Xi Yunshu stands out in that he cites his own astonishment in the face of recent develop-

${ }^{34}$ Yi 2001a, Xu Jiang 2001, Xie Youshun 2001, Chen Zhongyi 2002a and 2002b, Zhang Qinghua 2002, Luo Zhenya 2005: ch 4, Zhu Dake 2006: 283-287. 
ments, realizing that an incompatibility of critical expectations and actual poetic production cannot be blamed exclusively on the poets. Such incompatibility and the resulting crisis discourse are of course nothing new, in China or elsewhere. Wu Sijing has suggested that in the contemporary Chinese case, the mismatch of poetry and criticism and the particularly acute crisis discourse of the late 1990s go back to the mid-1980s. Then, the new poetry's sheer abundance and its extraverted presentation began to drown out and ignore its commentators or, in Wu's words, struck them speechless - not least because it produced aesthetic trends that were incomprehensible and unacceptable even to critics who were generally sympathetic to the avant-garde..$^{35}$

The defining publications of the Lower Body show them as including twelve authors, all born between 1970 and 1980, two of them women: Shen Haobo, Yin Lichuan ()), Sheng Xing, Li Hongqi, Nanren, Duoyu, Wu Ang (P), Zhu Jian, Ma Fei, Xuanyuanshike, Li Shijiang and A Fei. Loosely organized as it was - on the basis of a broadly defined literary affinity - the group can also be seen to include the work of other authors: Shu, for instance, who made a well-received contribution to the BNU recital. That most of the poets are men helps explain their macho-sexist style, which became self-perpetuating as the Lower Body gained momentum. In their turn, women poets Yin Lichuan and Wu Ang did little to subvert conventional gender patterns, if we recognize that images of femmes fatales do not advance female emancipation. A remarkable thing about the Lower Body was that the authors put forth a consciously hip visual presentation, which was uncommon in literary circles at the time but has since spread far beyond the unofficial journals that initiated it. This was very much a sign of the times, with visual media encroaching on the hegemony of the written word, as noted in chapter One: impossible camera angles, flippant postures, wild hairdo's, Yin Lichuan lighting cigarettes with her face averted, Shen Haobo's "Record of a Head Shave" (剃头记) and so on. These and similar images are part of a literary undertaking that is playful and dedicated at the same time.

For all their loudness and self-indulgence, the Lower Body poets by no means saw their undertaking as the measure of all things and were more inclined to self-mockery than most of their contemporaries. They happily accepted that many of their poems were little more than

${ }^{35}$ Wu Sijing 1996. 


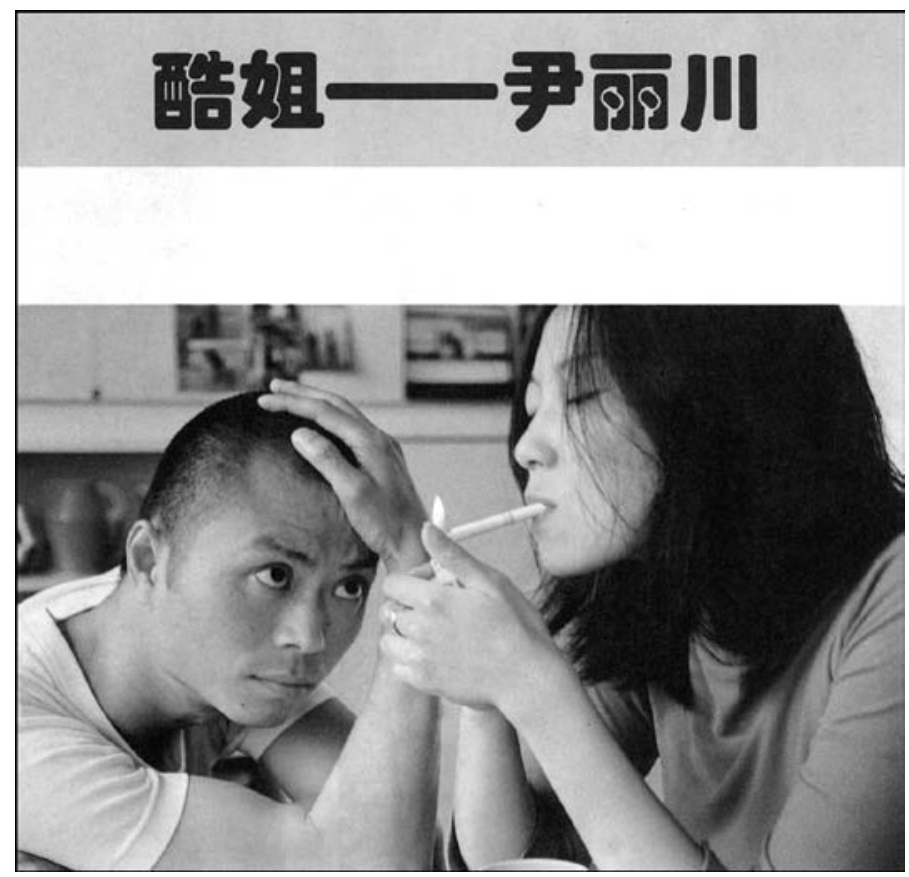

Figure 9.4. "Cool sister" Yin Lichuan (Poetry Text 4 [2001]: 10)

fleeting ideas and impressions written up with line breaks: provocative, perhaps even shocking or absurd, worth reading but not rereading. This would make their texts little more than zeitgeist commentaries that could just as well have availed themselves of genres other than poetry, such as political pamphlets, newspaper editorials and social science reports.

Or could they? For the Lower Body's best poems it is precisely the fact that their authors did not write pamphlets, editorials and reports that leads one to reflection on the genre of poetry and reaffirms that the Lower Body is more than a succès de scandale, in spite of censorial reflexes such as Ma Ce's. These have always befallen lawless literature, and they always will.

Why poetry? Contrary to Shen Haobo's manifesto, the Lower Body has all sorts of things to do with knowledge, culture and tradition, and even with poetic sentiment, albeit in a new time and a new style; and maybe with lyricism and philosophy as well, for even a minimalist poetics makes poetry the precipitation of such things, conscious or un- 


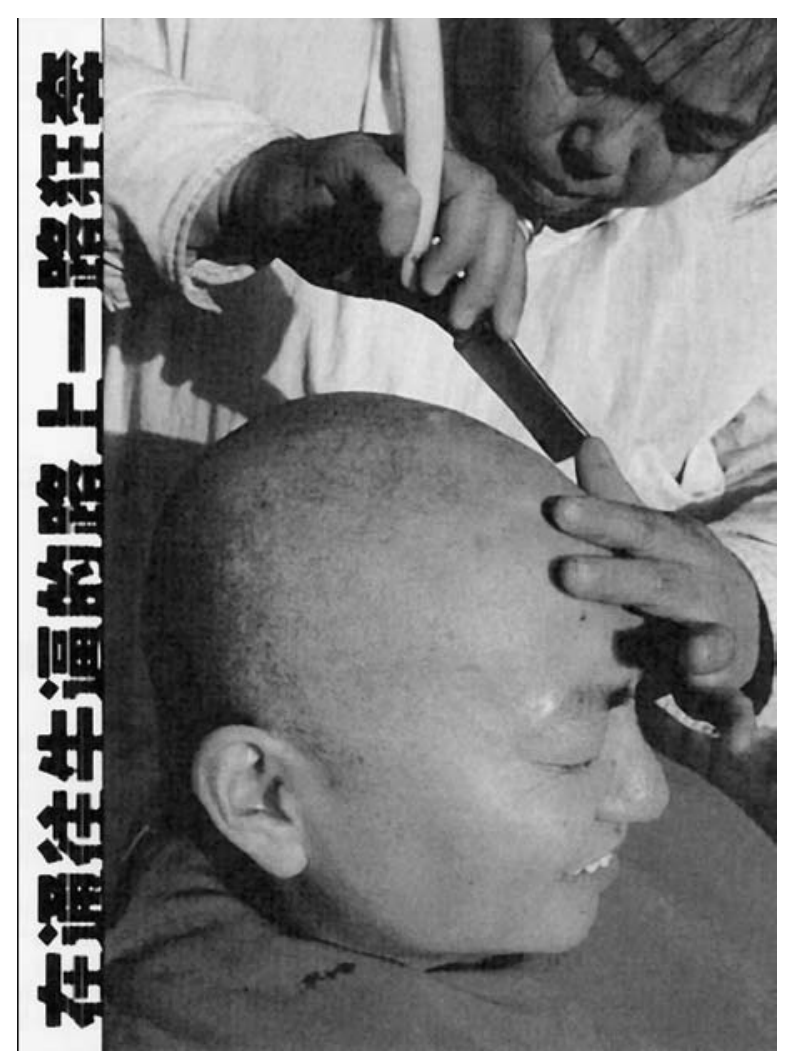

Figure 9.5. "Running Wild on a Crash-Hot Road": Shen Haobo's "Record of a Head Shave" (Poetry Vagabonds 1 [2001]: 12)

conscious. The Lower Body's alleged unconcern is debatable along similar lines. One who is truly unconcerned doesn't write - unless one writes for the money, but Lower Body poetry is financially even more unmarketable than most other avant-garde texts. In fact, Lower Body poetry does display a palpable concern with not just the horrors of a time of radical social change but also its pleasures. But the crux of the matter is poetry's ability to be about something else and yet, as an artifact, be about itself and draw attention to itself: to connect with others and yet stand alone. Lower Body poetry happens on the interface of its rootedness in the reality of its surroundings and art's right to be elsewhere. It couldn't do without either. 


\section{A Poetia Lineage}

Lower Body poetry didn't appear out of nowhere. Below, I will briefly sketch its lineage within the avant-garde, with reference to the Elevated and Earthly aesthetics - again, not as pigeonholes but as coordinates in a multidimensional body of texts and metatexts, to help us to identify overall trends within the avant-garde and kinship between individual oeuvres.

For positioning themselves during their heyday in the years 2000-2002, Lower Body poets often referred to the notion of the Popular as this had been advertised during the Polemic in 1998-2000. For them, the Polemic derived its status as a frame of reference from the fact that it had brought the divergence of the Elevated and the Earthly to a head during their formative years as poets. Incidentally, Shen Haobo was by no means uncritical of the Popular, but his discontent in this respect pales in comparison with his vicious attacks on anything that could be remotely associated with Intellectual Writing. ${ }^{36}$ At any rate, the Lower Body is one of several extreme manifestations of the Earthly orientation in the early twenty-first century, two others being the Trash School and the Low Poetry Movement of subsequent years, studied in recent research by Heather Inwood and Michael Day respectively. ${ }^{37}$ Explicit poetics and other comments by Lower Body authors confirm its affinity with the Earthly. For outlining its provenance we focus on three salient features.

\section{Demystification}

What I have called the rejective quality of Lower Body poetry is also visible in Shen Haobo's manifesto, as one of many deconstructions of high-blown images of poethood by Shen and others. As such the Lower Body partakes in a poetics of demystification and indeed desecration that is discussed at various points in this study. This poetics goes back to authors such as Han Dong, Yu Jian and Yi Sha and journals such as Them and Not-Not. In its early stages, it is to some extent negatively defined as the rejection of Obscure Poetry. Later, it finds itself in opposition to many of the categories on the Elevated side in the list

\footnotetext{
36 For Shen's criticism of the Popular, see Shen Haobo $2001 b$.

37 Inwood 2008: ch 2, Day 2007a.
} 
of dichotomies that make up the contrast of Elevated and Earthly outlined in chapter One: the "lyrical," the "mythical," the "utopian," the "Westernized" and so on. It bears reiteration that the poetry of demystifiers from Han Dong to Shen Haobo far transcends their resistance to other poetries, as I hope to have shown in the preceding pages.

By way of concrete examples, some of which have been previously discussed, Han Dong's «Of the Wild Goose Pagoda» and «So You've Seen the Sea» effectively deconstruct canonical landmarks of Chinese civilization and clichéd, inflated imagery. Yi Sha's poetry does something similar, famous texts being «As the Train Crosses the Yellow River» (车过黄河, 1988) and «Starve the Poets», with the latter specifically targeting Haizi and his epigones. More explicitly than Han Dong in «So You've Seen the Sea», Yi Sha proceeds from a perceived abuse of poetic imagery to contempt for the arrogance of poet-hood. Yu Jian's oeuvre, most notably «File 0», extends demystification to the sacred status of poetic language. ${ }^{38}$

\section{Bad Behavior}

Another feature of Lower Body poetics that builds on earlier trends in its literary surroundings is that of being unruly and offensive in conventional terms. That is, conventional within the avant-garde, to say nothing of government-sanctioned literary orthodoxy. This poetics of bad behavior manifests itself in the systematic breaching of (socio-)sexual and other bodily taboos such as prostitution, substance abuse, masturbation, defecation, urination, disease and violence; in the denigration of education and learning, often through association with these taboos; and in the shameless display of sexism, specifically misogyny, homophobia and a general machismo. Here, too, there are well-known precedents and parallels, overlapping with the category of demystification. Yet again, one thinks of Yi Sha. Other, earlier authors that come to mind include Macho Man Li Yawei and Not-Not poet Yang Li. Notably, the impact of their bad behavior went well beyond poetry. According to Zhu Dake, the cradle of "hooligan discourse" in other literary genres and art in contemporary China stood in avantgarde poetry of the 1980 s. $^{39}$

${ }^{38}$ Han 2002: 10, 14; Yi 1994: 5, 3; Yu Jian 1994.
${ }_{39}$ Zhu Dake 2006: ch 6. 
«The View Is Limitless» (风光无限, 1999), the first poem in Yi Sha's second officially published collection of poetry, opens with the joys of defecation linked to the classical-literary topos of ascending a mountain to take in the view. This and other taboos occur throughout his oeuvre, such as in "Address at a Seminar on Women's Literature» (在女性文学研讨会上的发言, 1997) and «My [Academic] Advisor and I» (我和我的导师, 1996). An early instance of the denigration of higher education is Li Yawei's «The Chinese Department» (中文系, 1984). Simultaneous with the emergence of the Lower Body, Yang Li published «Fire the Cannon» (打炮, 1999?), a long-drawn out account of mostly prostitutional sex, firing the cannon being phallocentric slang for intercourse and ejaculation. The poem first appeared in 2000 in Poetry Reference. In addition to many other types of poetry, this influential, long-standing unofficial journal has consistently given the poetics of bad behavior opportunities for publication. So has Original Writing, which carried «Fire the Cannon» in 2001. ${ }^{40}$

\section{Social Concern}

Of special interest in this literary-genealogical exercise is Lower Body poetry's expression of social concern. I use this broad notion specifically to refer to the fact that many Lower Body poems engage with issues of social justice and discontent that result from present-day China's radical transformation. One example is the widening gap between urban and rural lives and livelihoods, and generally between haves and have-nots and the powerful and the powerless. Another is young people's rejection of socialist ideology and its institutions, not to say their indifference to these things, certainly since the 1990s. This is starkly visible in an overall incompatibility of experience from one generation to the next, in areas ranging from norms and values for social relations to tastes in fashion, music, literature and so on. Shen Haobo's and Yin Lichuan's poetry illustrates this point, which is driven home by the astonished reactions of several of their critics.

Not just since the 1990s, a decade that has inspired views of China as a postsocialist and jungle-capitalist society, but in fact ever since the avant-garde's early years there have been many examples of socially

${ }^{40}$ Yi 1999a: 1-44, 125; Zhongdao 1998: 259; Li Yawei 2006: 6-11; Original Writing 2 (2001): 4-9. 
concerned authors of Earthly persuasion. This includes those writing in Them in the mid-1980s as well as authors associated with the Low Poetry Movement whose sense of social responsibility has been pointed out by Day, and self-styled philosopher and musician Wenmang (1977) - a name meaning 'illiterate' - who describes the inside of a psychiatric institution in «Burn to Death All You Fucked-Up People» (烧死你们这些狗日的, 2002). ${ }^{41}$ Wenmang's belligerent title addresses the institution's authorities, not the patients: he portrays the latter with compassion. Notably, however, unlike demystification and bad behavior, the poetics of social concern is not at all exclusive to oeuvres that can be subsumed under the Earthly orientation. It is something the Lower Body has in common with authors from across the array of styles that have made up the avant-garde in the past decades - and there is, of course, an interface here with traditional Chinese views of poetry.

The best-known example of social concern at the Elevated end of the spectrum lies in the humanist orientation of much late 1970s and early 1980s Obscure Poetry, in texts such as Bei Dao's «Declaration», Shu Ting's «Motherland, My Beloved Motherland» and Jiang He's «Monument». In hindsight these poems, which marked the transition from Maoist orthodoxy to the avant-garde, border on socio-political pamphleteering. Later, artistically sophisticated examples of Elevated social concern are Wang Jiaxin's «Pasternak» (帕斯捷尔纳克, 1990) and Xiao Kaiyu's «The People's Bank» (人民银行, 1997). ${ }^{42}$

A final example of social concern as a notion bridging the gap between the Elevated and the Earthly - and one of particular relevanceis that of Yan Jun, in «Against All Organized Deception», which we will examine more closely in chapter Thirteen. Yan's poem is truly contemporary with the Lower Body and the similarities are striking. «Against» is anchored in present-day, rough-edged Chinese realities. It is streetwise, angry and energizing, but it also displays self-mockery and humor. Its social concern is visible in Yan's depiction of things like the abuse of police power, the growing dominance of consumerism and entertainment culture, and ecological disaster. Unlike the Lower Body, however, «Against» is anything but cynical or decadent. It is a contemplative and seriously political poem with anarchist overtones.

${ }^{41}$ Original Writing 3 (2002): 39-41.

${ }^{42}$ Yan Yuejun et al 1985: 19, 42-43, 190-192; Wang Jiaxin 1997: 64-66, Xiao Kaiyu 2004: 57-58. 
As for literary technique, it employs an abundance of associative and imaginative imagery in a prose-poetic form that strongly recalls $\mathrm{Xi}$ Chuan's work. In this respect, it also displays kinship with the Elevated aesthetic. $^{43}$

Poets like Shen Haobo and Yan Jun have more to say than can be handled within an "autonomous" realm of literature. As such, their predecessors in modern times range far and wide, from Liang Qichao in China to Marinetti in Italy, to name but two examples of roughly a hundred years ago. The work of Liang comes to mind because it stands at the beginning of modern Chinese literature; that of Marinetti, because the texts of Futurism, just like Shen's and Yan's, are driven and defiant if not aggressive, and marked by the phenomenon of learning and culture ostensibly turning on themselves. Crucially, both Liang and Marinetti consider art that explicitly positions itself in relation to its extra-literary surroundings capable of effecting social change. In fact, especially for Liang but also for Marinetti, the projection of social change is a point of departure for literature rather than its possible conclusion. ${ }^{4}$

As a common feature of diverse oeuvres in the Chinese avant-garde, and one that transcends the dichotomies that have led me to identify the Elevated and Earthly aesthetics, social concern is firmly rooted in today's extra-literary realities. In many other places contemporary poetry tends to function as a buffer against the world outside literature instead. In China, poetry as the expression of social concern stands in a long, strong tradition that makes it a self-evident extension of the poet-official's involvement in governing the state and actively contributing to the well-being of society. In spite of modern poets' declared dissociation from China's literary past, this aspect of traditional poetics is one of several factors that inform the work of numerous authors from the Republican and Maoist periods, and from the early years of the Reform period - as well as that of younger generations such as the Lower Body poets, albeit irregularly and in provocative, noninstitutional or indeed anti-institutional fashion.

\footnotetext{
43 Yan Jun 2001: 149-152.

44 Martin 1973, Weber 1960: 241-246.
} 
Different from their predecessors, the Lower Body poets and authors like Yan Jun forgo claims to poethood as a means of speaking for others and something that confers high status. At the same time they pursue personal publicity and fame, or at least they don't eschew these things. Their glamor is that of being hip and disaffected but still making a difference in terms of social engagement. Any easy dismissal of this duality in their work turns a blind eye to fascinating relations between social change and cultural development in China today. 